\title{
Heavy Metal and Water Quality Status of Well, Spring and Reservoir Waters in Medawachchiya, Kebithigollewa and Padaviya in Anuradhapura District
}

\author{
Abeysiri H.A.S.N., Manage P.M.* \\ Centre for Water Quality \& Algae Research, Department of Zoology, \\ University of Sri Jayewardenepura, Sri Lanka \\ *pathmalal@sjp.ac.lk
}

\begin{abstract}
Ground water is the main source of drinking water particularly among the farming community in the North Central Province. They use more fertilisers for their farming activities. Recent study was carried out to determine the heavy metal contamination along with water quality on the randomly selected wells, springs and reservoir water in Medawachchiya, Kebithigollewa and Padaviya in the Anuradhapura District. Five well water samples in Medawachchiya, four spring water samples in Kebithigollewa, nine well water samples in Padaviya and nine reservoir water samples in the Anuradhapura District in the wet season were subjected to analysis. Water temperature, $\mathrm{pH}$, conductivity, Dissolved Oxygen (DO) were measured at the site itself using standard methods. $\mathrm{N}^{-\mathrm{NO}_{3}}{ }^{-}, \mathrm{N}-\mathrm{NO}_{2}{ }^{-}, \mathrm{N}-\mathrm{NH}_{3}$, Total Phosphorous and total Hardness were measured by standard spectrophotometric and titrimetric methods. Concentrations of heavy metal, $\mathrm{Zn}, \mathrm{Cr}, \mathrm{Cd}, \mathrm{Cu}$ were determined by using Graphite Fernance Atomic Absorption Spectrometry (GFAAS). The water temperature, $\mathrm{pH}$, conductivity, Dissolved Oxygen (DO) varied between 26.4 and $32.8\left({ }^{\circ} \mathrm{C}\right), 6.92$ to $7.48,77.6$ to $998 \mu \mathrm{S} / \mathrm{cm}$ and 1.38 to $9.98 \mathrm{mg} / \mathrm{l}$ respectively. $\mathrm{N}^{-\mathrm{NO}_{3}}{ }^{-}, \mathrm{N}-\mathrm{NO}_{2}{ }^{-}, \mathrm{N}-\mathrm{NH}_{3}$ ranged between $<0.01$ to 0.44 $\mu \mathrm{g} / \mathrm{l},<0.01$ to $0.97 \mu \mathrm{g} / \mathrm{l}$ and $<0.01$ to $0.97 \mu \mathrm{g} / \mathrm{l}$. Total Phosphorous and Total Hardness ranged between $<0.01$ to $0.44 \mu \mathrm{g} / \mathrm{l}$ and 1.97 to $73 \mathrm{mg} / \mathrm{l}$ respectively. All the tested general water quality parameters were within the SLSI standards given for drinking water. $\mathrm{Cr}, \mathrm{Cd}, \mathrm{Cu}$ and $\mathrm{Zn}$ concentrations ranged between 4.06 to $227.75 \mu \mathrm{g} / \mathrm{l}, 0.32$ to $6.21 \mu \mathrm{g} / \mathrm{l}, 14.86$ to 86.91 $\mu \mathrm{g} / \mathrm{l}$ and 24.86 to $87.84 \mu \mathrm{g} / \mathrm{l}$ respectively. $70 \%$ of samples exceeded SLSI drinking water standards for $\mathrm{Cd}$ and $\mathrm{Cr}$ concentrations in well water samples in Padaviya. Heavy metal concentrations in $30 \%$ of well water and all spring water samples were within the SLSI drinking water standards. Thus, it is concluded that general prior treatment is needed before consuming ground water.
\end{abstract}

Keywords: Water quality, Heavy metals, Anuradhapura District 